\title{
What are we Talking about when we Talk about Memphis?
}

\author{
Maria Helena Trindade LOPES
}

\begin{abstract}
The different uses of the term Memphis, the difficulty in determining its exact location, its extension, its permanence in time as an influential metropolis, and the reasons for its "disappearance" are the main questions addressed in this work.

Los problemas que trata este artículo son los diferentes usos del término Menfis, la dificultad en determinar su ubicación exacta, su extensión, su permanencia en el tiempo como una metrópolis influyente y las razones para su "desaparición".
\end{abstract}

Keywords: Memphis, nome, royal necropolis, capital, religious centre. Palabras clave: Menfis, nomo, necrópolis real, capital, centro religioso.

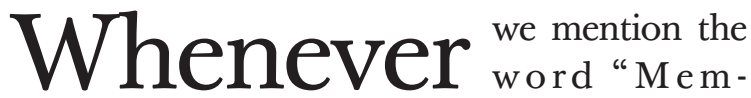
phis"1 in a conference, a classroom or in any academic discussion, our thoughts, and those of our audience, wander immediately to a city that is considered to be the most ancient and greatest dynastic capital of Pharaonic Egypt. Strategically situated between the North (Lower Egypt) and the South (Upper Egypt)-consequently known by the epithet "The Balance of the Two Lands" ( $m h 3 t$ t $3 w y$ ) - it was founded by the first king of Egypt around the year 3100 BC according to Egyptian myths and classical legends ${ }^{2}$. However, this is not such a simple question. As S. Love states, "there are several different uses for the name, each having different, yet specific, geographical references. The name Memphis can refer to either the nome, the royal necropolis, the capital city, the city-centre or the pyramid town of Pepi I" (fig. 1) ${ }^{3}$.

The term Memphis does, in effect, designate the first nome, or province, in Lower

1 For a study of Memphis and the Memphite region: Snape, 2014: 170-177; Leclère: 2008: VII-VIII, 25-111; Love, 2003: 70-84; Franke, 2003; Martin, 2000: 99-120; Jeffreys, 2000: 24-27; Jeffreys, 1999: 448-49o; Koenig, 1998: 248; Málek, 1997: 90-101; Jeffreys, 1997: 8-9; Jeffreys and Giddy, 1992: 6-7; Jeffreys and Giddy, 1991: 5-8; Thompson, 2012; Zivie, 1988; Smith and Jeffreys, 1986: 88-95; Jeffreys, 1985; Kamil, 1983: 25-32; Zivie-Coche, 1982: 24-41; Kitchen, 1973: 87-104; Anthes, 1965; Anthes, 1959; Dimick, 1956; Badawy, 1948; Petrie, 1910; Petrie, 1909.

2 Snape, 2014: 171.

3 Love, 2003: 71.

TdE 7 (2016) - Páginas: 59-66
Recepción: 10/10/2016 - Admisión: 02/11/2016
Maria Helena Trindade Lopes - helenatrindadelopes@hotmail.com
Centro de História d'Aquém e d'Além-Mar / Faculdade de Ciencias Sociais e Humanas / Universidade Nova de Lisboa,
Universidade dos Açores / Portugal
http://doi.org/10.25145/j.TdE.2016.07.04




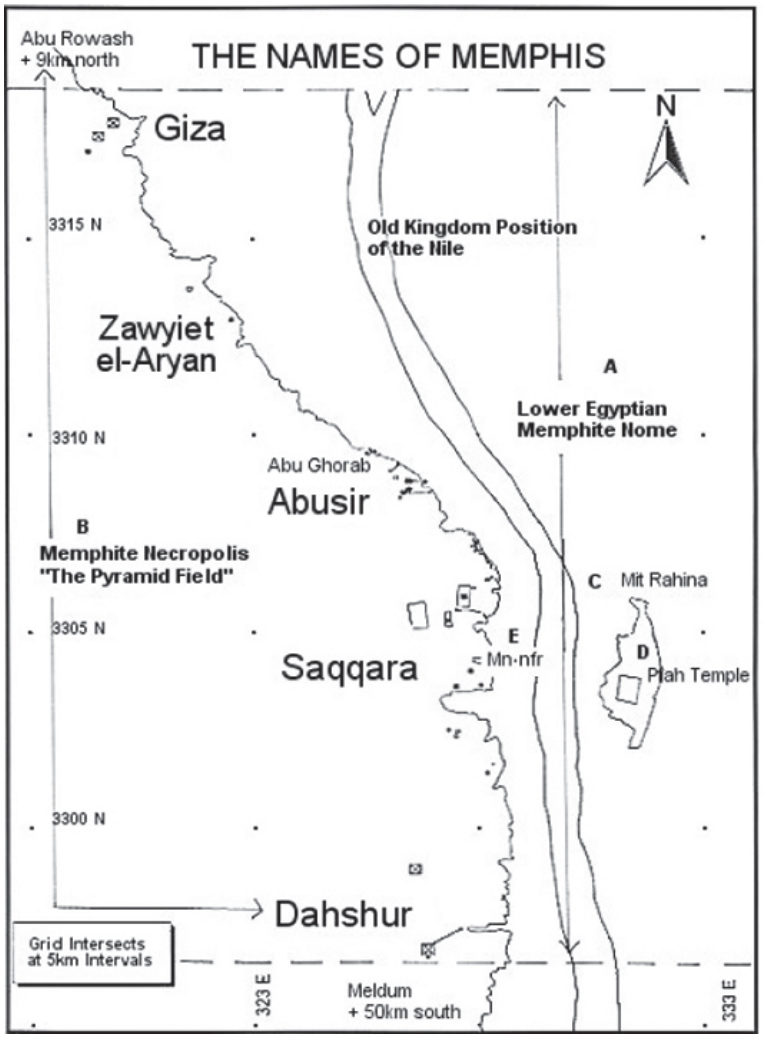

Figure 1. The names of Memphis. In Love, 2003: 72.

Egypt. But when we refer to its extensive necropolis, interestingly, we use the same word: "the Early Dynastic tombs and the Old Kingdom pyramids and private cemeteries are often termed as the 'Memphite Necropolis'. This necropolis stretches for 80 kilometres and is defined by the northern-most pyramid at Abu Rowash and the southern pyramid at Meidum"4. Yet the most relevant and traditional connotation of the word is conceivably the one that denotes the oldest capital of Pharaonic Egypt, located to the East of the necropolis of Saqqara ${ }^{5}$. Today this region is known by the Arabic name of Mit Rahina and is characterised by the ruins of the monuments preserved in situ. According to Love, "the 'capital of Memphis' is also referred to as the Ptah temple of Mit Rahina as the city centre, the heart of the social, religious and commercial area" ${ }^{\text {. }}$. What's more, the term "'Memphis' is a Greek-derived word, stemming from the hieroglyphic name, $M n-n f r$, after the pyramid town of the Sixth Dynasty king Pepi I"7. To all these specifications for the same word it must also be added that of White Walls (jnbw $h \underline{d}$ ), being possibly the earliest appellation used by the ancient Egyptians for the area later referred to as the capital ${ }^{8}$.

\section{Therefore, what are we actually talking about when we talk about Memphis?}

The earliest information about the importance and extension of Memphis was provided by classical authors, historians like Herodotus and geographers like Strabo and Diodorus of Sicily9. They described a place that, during its last phase, seems to correspond to the actual site of the ruins of Mit Rahina. However, none of them ever refer to Memphis as the capital.
4

5

6

7

8 See Edwards, 1971: 1-17. The discussion about the existence and location of these "White Walls" remains open since there is no archaeological evidence of its location. See Málek, 1997: 90-101.

9 See: Jeffreys, 1985: 6 and 11; Love, 2003: 72-74. 
There are later references in medieval Arabic literature ${ }^{10}$ (Abd el-Latif, el-Qalqashandi and el-Maqrizi) and in travellers' reports ${ }^{11}$ (William of Tyre, Benjamin of Tudela, and Joos van Ghistele), but the haziness surrounding the real meaning of the term persists. The "identity" of the city was lost over time, and was only re-established in 1585 by François de Pavie ${ }^{12}$. Subsequently, the location of Memphis became an important subject of academic debate, though the first detailed maps of the area only appear at the very end of the eighteenth century in the wake of Napoleon's expedition. Curiously, Vivant Denon, one of the 167 savants that accompanied the emperor, mentions in his reports that the northern and southern borders of the old city of Memphis were delimited by two pyramid complexes: Giza to the north and Saqqara to the south ${ }^{13}$.

This idea of associating the city with the pyramid complexes-Giza and/or Saqqarawas echoed by other travellers and scholars. But it was the members of Napoleon's scientific expedition to Egypt who would associate the old capital, Memphis, with the field of ruins at Mit Rahina. One of the reasons for this association was obviously the density of archaeological vestiges found there ${ }^{14}$.

Nonetheless, discussion about the city's extent continued for a long time. William
F.M. Petrie, who led six seasons of excavations in the area between 1909 and 1913, calculated that the city of Memphis had stretched approximately $13 \mathrm{~km}$ from north to south and $6.5 \mathrm{~km}$ from east to west, including suburbs and gardens ${ }^{15}$. His map of the site, based on the one produced by Karl $\mathrm{R}$. Lepsius during the excavation in Kôm Rabi'a in $1843^{16}$, was used as the basis for research for many years. A new map was only produced when Rudolf Anthes undertook another expedition to Memphis between 1955 and 1956, sponsored by the University of Pennsylvania ${ }^{17}$.

Since 1987, David Jeffreys and Lisa Giddy have been conducting a survey of Memphis, sponsored by the Egypt Exploration Society, stating that in the most relevant period, "Memphis was a vast metropolis that stretched at least $10 \mathrm{~km}$ from north to south"18. The recent work carried out on settlement of the area seems, effectively, to show that Memphis was more extensive than had initially been thought ${ }^{19}$.

However, why is it that a city that had been a capital for over a thousand years (from 3100 $\mathrm{BC}$ to $2100 \mathrm{BC}$ ) has so few remaining vestiges? The map provided by Jeffreys in 1985 of the remaining vestiges of the Old Kingdom in the area of Mit Rahina and Saqqara has surprisingly few references (fig. 2).

10 Jeffreys, 1985: 11.

11 Jeffreys, 1985: 11-12.

12 Jeffreys, 1985: 12.

13 Love, 2003: 74.

14 See Love, 2003: 75-76.

15 Jeffreys, 1985: 6-7.

16 Jeffreys, 1985: 13. The first systematic report of the "field of ruins" was presented by Karl R. Lepsius.

17 Jeffreys, 1985: 16.

18 Jeffreys, 1985: 13 .

19 Jeffreys, $1985: 16$. 


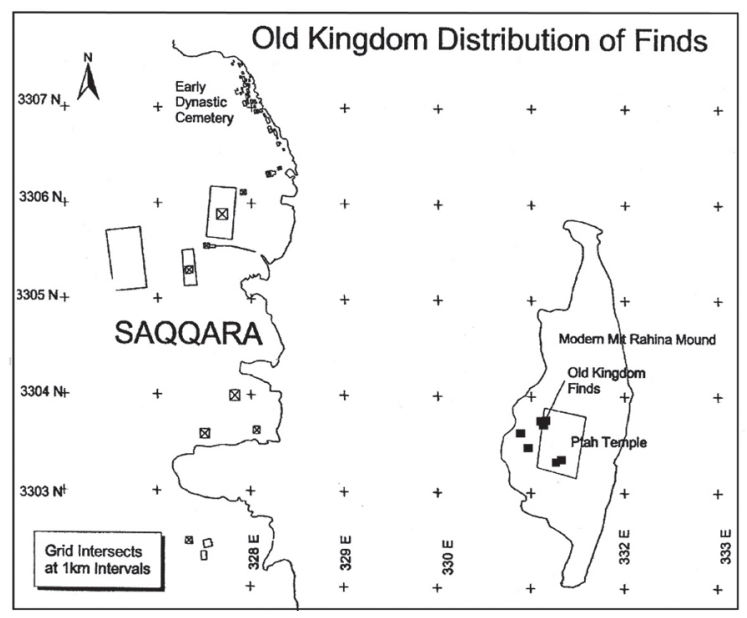

Figure 2. Map of the vestiges of the Old Kingdom, 1985. In Love, 2003: 77.

\section{What could have happened to the face of Memphis?}

As Love clearly explains, recalling the works of Butzer and Hassan"20, "the rate of sediment accumulation in the valley floor of the Memphite region is estimated at one metre per millennia $[\ldots]$ This would place a second millennia BC settlement several metres below the modern ground surface" ${ }^{21}$. Thus, according to Jeffreys, the Old Kingdom ground level is four metres below the area west of Mit Rahina ${ }^{22}$.

Another element that interfered with the recovery of archaeological remains was the change of course of the Nile ${ }^{23}$, which over the centuries was progressively diverted to the east, provoking natural erosion of the oldest ruins in the $\operatorname{site}^{24}$ (fig. 3).

Finally, the last explanation for these curious occurrences is related to the activity of sebakh-diggers who over the centuries have been stealing the adobe from Memphite monuments to use as fertiliser in agriculture $^{25}$. Of course occupation and construction in later periods, like that which took place during the strong presence of the Saite dynasty in the Late Period ${ }^{26}$, which restored Memphis to the status of royal residence, could also have devastated older remains, as L. Giddy suggests ${ }^{27}$. But the man that best knows Memphis and its settlement, David Jeffreys, produced a new map in 1994 of the Memphite ruins, based on an alternative technique called "drill cores" 28 , which consists of deep subsoil borehole surveys. This map has enabled to visualise another level of settlement in the first dynasties and in the Old Kingdom, in the area of Mit Rahina and surrounding area (fig. 4).

Therefore, I again pose the question:

\section{When we talk of the ancient capital of Memphis, what exactly are we talking about?}

We are talking about an area that is not limited to present day Mit Rahina, but extends to Saqqara, Abu Rowash, Giza, Abusir

20 Jeffreys, 2000: 24 .

21 See Love, 2003: 76-79.

22 See Jeffreys, 1997b: 2-4.

23 See Jeffreys and Tavares, 1994: 143-173; Jeffreys, 2008b: 6-7.

24 Love, 2003: 78.

25 See Lopes, 2010: 25 and Kemp, 1976: 27.

26 See Lopes, 2010: 22 and 27 ss.

27 See Giddy, Jeffreys and Málek, 1990: 13.

28 See results of the use of the technique in Abu Rowash, Giza, Abusir, Saqqara and Dahshur in Love, 2003: 79-81. 


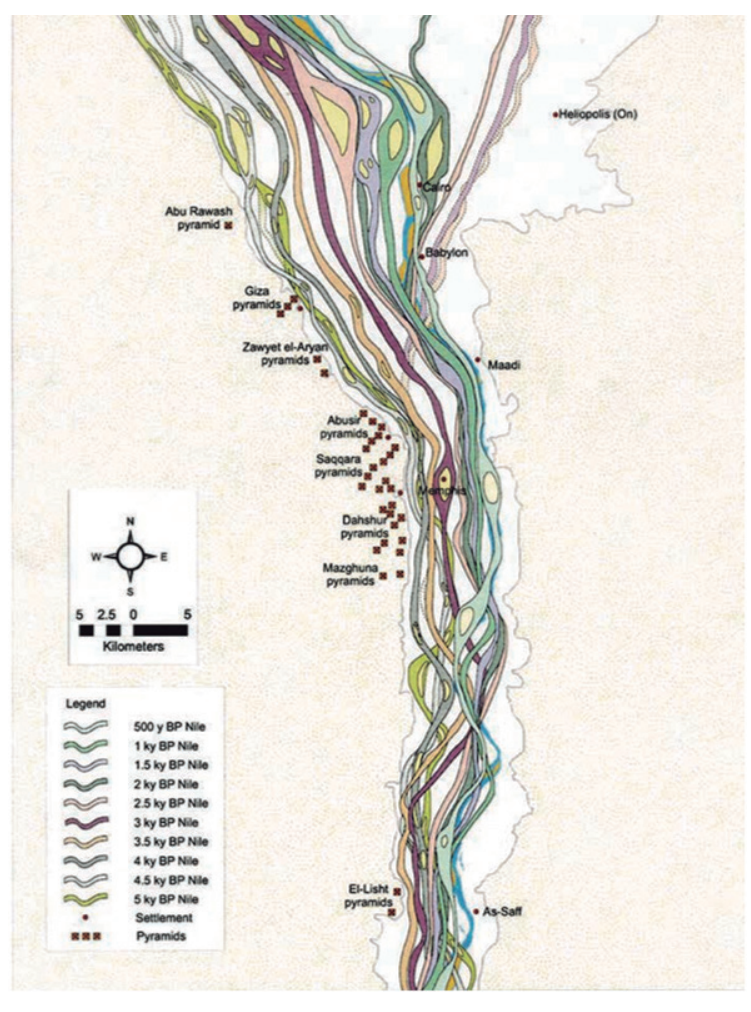

Figure 3. Computer model of Nile movement over the past 5000 years. By K. Tutley, University of Cambridge, Earth Sciences Department. In Jeffreys, 2008: 42.

and Dahshur'29. Like Love suggests, "perhaps now Memphis may be considered a dynamic urban centre. It is possible that Old Kingdom Memphis was not confined to one small, nucleated settlement area but rather extended throughout the entire Memphite region"30 (see fig. 1).

The great economic momentum that developed around the city's temples and necropolises (Saqqara, Abu Rowash, Giza, Abusir and Dahshur), along with a privileged geographical situation that enabled it to control the Delta and the confluence of desert trade routes from the Levant and Red Sea to the Sahara $^{31}$, made it an obvious economic centre. A capital that also became one of the largest religious centres of the country-with its tutelary god Ptah, the creator god who conceived the world in his heart and brought it into being by the strength of his word-and a great centre of culture, art and intellectual activities in Pharaonic Egypt. In its libraries and workshop manuals, treatises, canons and knowledge about sacred monuments were preserved and transmitted. Even after Memphis lost its status as capital to other provincial cities like Thebes, Per-Ramesses and Amarna in the Middle $^{32}$ and New Kingdoms ${ }^{33}$, it continued

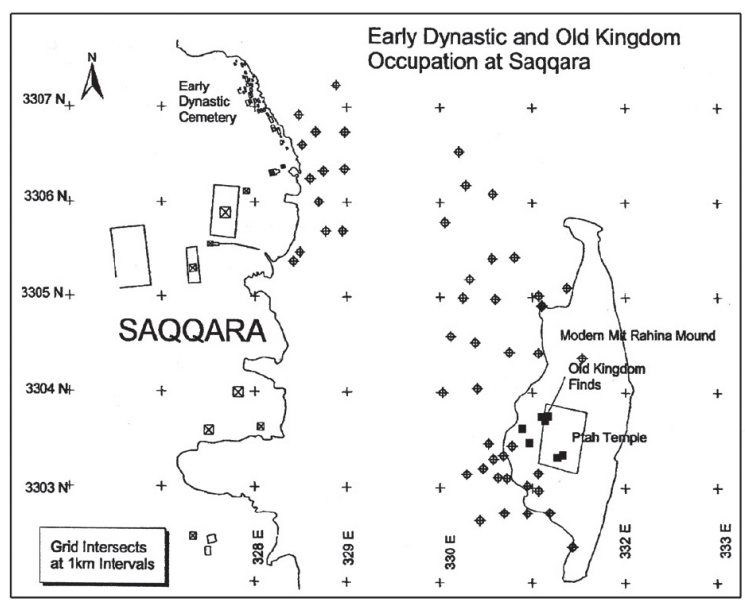

Figure 4. Distribution of drill cores in and around Mit Rahina: the symbols represent individual drill cores that are positive indicators of occupation. After Jeffreys and Tavares, 1994, in Love, 2003: 78.

29 Lehner, 1997: 7 and 15.

30 Love, 2003: 81 and Leclère, 2008: 39 .

31 Jeffreys and Giddy, 1991: 5 .

32 On the location of Memphis during the Middle Kingdom, see Snape, 2014: 173 and Leclère, 2008: 40-41.

33 To confirm the relevance of Memphis in the New Kingdom, see Martin, 2000: 99-120; Leclère, 2008: 41-55 and the most recent work of S. Pasquali (2011). 
to maintain an important position throughout Pharaonic history, and came to be the largest population centre in Egypt ${ }^{34}$. During the New Kingdom, for example, Memphis was a very cosmopolitan metropolis, an important centre of international trade, and a fundamental military base for the Empire ${ }^{35}$.

Its status as the city of tradition, where the first kings carried out the rite of "raising the Djed-pillar" ${ }^{6}$ to ensure the pharaoh a stable reign, led several kings throughout history to celebrate their royal jubilee (heb-sed) in Memphis and build their funerary temples there 37 ; this "fulcrum between the North and the South" was the site of ideological legitimisation, par excellence, of the Egyptian territory.

During the Late Period, Memphis once again became the main metropolis of the country and an important local residence ${ }^{8}{ }^{8}$. During the Saite Period, which corresponds to the Twenty-sixth Dynasty 39 and spans approximately a century and a half of Egyptian history between the invasions from the east-the Assyrians in the first part of the seventh century $\mathrm{BC}$, and the Persians in $526 \mathrm{BC}$-the city recovered its old splendour. As David Jeffreys affirms ${ }^{40}$, it became a cosmopolitan capital, enhanced by different foreign communities ${ }^{41}$, and an international port. Furthermore, "when Alexander the Great conquered Egypt in $332 \mathrm{BC}$ it was from Memphis that the country was governed. It was to this city that his general Ptolemy, son of Lagos, brought the conqueror's corpse following Alexander's death in 323 BC" 42 . However, in the Ptolemaic Period, despite the coronation ceremonies still being held there ${ }^{43}$, the city $^{44}$ started to loose importance in favour of

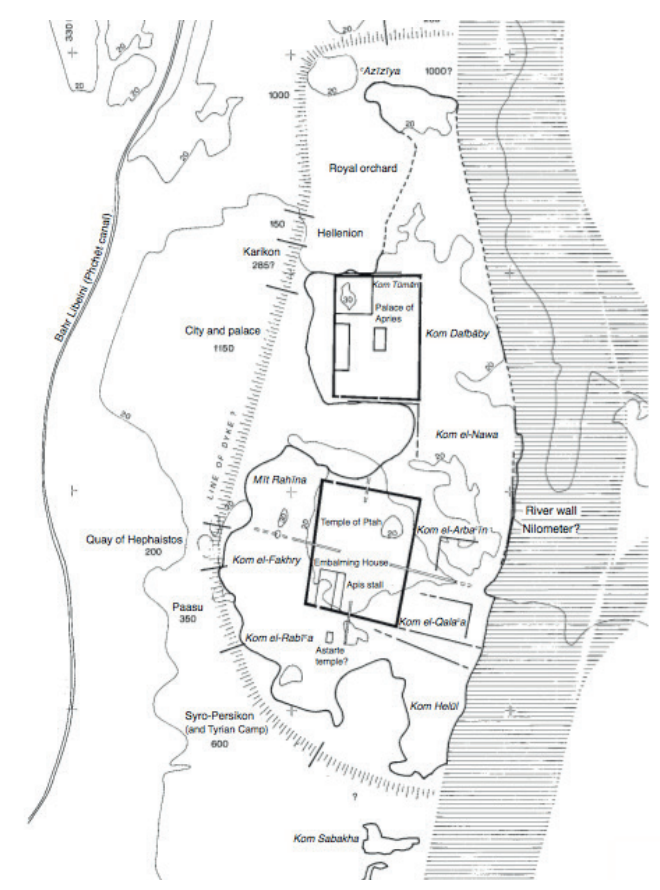

Figure 5. Memphis, general plan of the site. In Thompson, 2012: 12.

34 See Snape, 2014: 170.

35 The idea that "Perunefer" was the port of the city of Memphis is now practically accepted among researchers. See Snape, 2014: 173 and also Jeffreys, 2006: 36-37.

36 Kees, 1977: 150.

37 Kitchen, 1982: 162.

38 See Leclère, 2008: 61-72.

39 On this period, see Spalinger, 1977: 221-244.

40 Jeffreys, 2008: 44 .

41 See Leclère, 2008: 70-72.

42 Thompson, 2012: 2.

43 Jeffreys, 1999: 488.

44 For a perception of Memphis during the Ptolemaic period, see Thompson, 2012: 6 ss. and also Leclère, 2008: 8o-86. 
What are we Talking about when we Talk about Memphis? Maria Helena Trindade Lopes

Alexandria, which became the great metropolis and the most important commercial port of Egypt (fig. 5).

In the Roman Period, Memphis' decline was exacerbated by the construction of the fort of Babylon ${ }^{45}$, while during the Middle Ages Memphite monuments were systematically dismantled or destroyed and their stones re-used in the construction of several churches and mosques in Cairo.

Today Memphis is a vast field of ruins, but the "city that disappeared", buried by modern construction and pillaged by the sebakhim and those who dismantled the Memphite monuments, remains alive and questioning history...

\section{Bibliography}

Anthes, R.

1959 Mit Rahineh 1955. Philadelphia.

1965 Mit Rahineh 1956. Philadelphia.

BADAWY, A.

1948 Memphis als zeite Landeshauptstadt im Neuen Reich. Cairo.

Diмick, M.T.

1956 Memphis. The City of the White Wall. Philadelphia.

EDWARDS, I.E.S.

1971 "The Early Dynastic Period in Egypt", in: I.E.S. Edwards, G.J. Gadd and N.G.L. Hammond (eds.): The Cambridge Ancient History, Cambridge: 1-17.

Franke, D.

2003 "Theben und Memphis - Metropolen im Alten Ägypten", in http://www.ub.uni-heidelberg.de/archiv/3384.
Giddy, L.; Jeffreys, D.; MÁleK, J.

1990 "Memphis, 1989", fournal of Egyptian Archaeology 76: 1-16.

JEFFREYS, D.

1985 The Survey of Memphis, I. London.

1997a "Looking for Early Dynastic Memphis", Egyptian Archaeology 10: 8-9.

1997b "Excavation and Survey East of the Saqqara-Abusir Escarpment", Fournal of Egyptian Archaeology 83: 2-4.

1999 "Memphis", in: K.A. Bard (ed.): Encyclopedia of the Archaeology of Ancient Egypt, London: 488- 490.

2000 "Investigating Ancient Memphis, Pharaonic Egypt's northern capital", $A r$ chaeology International 3: 24-27.

2006 "Perunefer: at Memphis or Avaris", EA 28: 36-37.

2008a "The Survey of Memphis, capital of ancient Egypt: recent developments", Archaeology International 11: 41-44.

2008b "Archaeological Implications of the Moving of the Nile", Egyptian Archaeology 32: 6-7.

JefFreys, D.; Giddy, L.

1991 "Looking for Memphis", $E A$ 1: 5-8.

1992 "Towards Archaic Memphis", EA 2: 6-7.

Jeffreys, D.; Tavares, A.

1994 "The Historic Landscape of Early Dynastic Memphis", MDAIK 50: 143-173.

KAMIL, J.

1983 "Ancient Memphis. Archaeologists Revive Interest in a Famous Egyptian Site", $A r$ chaeology 38: 25-32.

KEMP, B.

1976 "A Note on Stratigraphy at Memphis", Fournal of the American Research Centre in Egypt 13: 27.

1989 Ancient Egypt: Anatomy of a Civilization. London.

Kees, H.

1977 Ancient Egypt. A Cultural Topography. Chicago, London.

45 Jeffreys and Giddy, 1991: 5 . 
Kitchen, K.A.

1973 "Towards a Reconstruction of Ramesside Memphis", in: R.E. Freed and E. Bleiberg, (eds.): Fragments of a Shattered Visage: Proceedings of the International Symposium on Ramesses the Great, Memphis: 87-104.

1982 Ramsés II, le Pharaon Triomphant. Paris.

Koenig, Y.

1998 "Memphis", in Dictionnaire de l'Egypte Ancienne, Paris: 248.

LECLÈRE, $\mathrm{F}$.

2008 Les villes de Basse Égypte au 1er millénaire av. F. - C. Cairo.

LEHNER, M.

1997 The Complete Pyramids. London.

LOPES, M.H.T.

2010 Mênfis: o rosto de Apriés. Lisboa.

Love, S.

2003 "Questioning the Location of the Old Kingdom Capital of Memphis, Egypt", Papers from the Institute of Archaeology 14: 70-84.

MÁleK, J.

1997 "The Temples at Memphis. Problems Highlighted by the EES Survey", in: S. Quirke (ed.): The Temple in Ancient Egypt: New Discoveries and Recent Research, London: 90-101.

Martin, G.T.

2000 "Memphis: the status of a residence city in the Eighteenth Dynasty", in: M. Barta and J. Krejci (eds.): Abusir and Saqqara in the Year 2000, Prague: 99-120.

Pasquali, S.

2011 Topographie cultuelle de Memphis 1 a-Corpus. Temples et principaux quartiers de la XVIIIe dynastie. Montpellier.

Petrie, W.F.

1909 Memphis I. London.

1910 Meydum and Memphis (III). London
SMith, H.S.; JefFreys, D.G.

1986 "A Survey of Memphis, Egypt", Antiquity LX: 88-95.

SNAPE, S.

2014 The Complete Cities of Ancient Egypt. London.

Spalinger, A.J.

1977 "Egypt and Babylonia: a Survey (c. 620 BC-55O BC)", SAK 5: 221-244.

Thompson, D.J.

2012 Memphis Under the Ptolemies. Princeton.

VERNER, M.

2002 The Pyramids: Their Archaeology and History. London.

WiLKINSON, T.

1990 Early Dynastic Egypt. London.

Zivie, A.P.

1988 Memphis et ses necrópoles au novel empire. Paris.

Zivie-Coche, C.

1982 "Memphis", in $L \ddot{A}$ IV, Wiesbaden: col. 2931. 
Trabajos de Egiptología

Papers on Ancient Egypt 


\section{Consejo editorial}

\section{Director}

Miguel Ángel Molinero Polo

Universidad de La Laguna, Tenerife, Islas Canarias

\section{Secretaría de edición}

Lucía Díaz-Iglesias Llanos

Centro Superior de Investigaciones Científicas, Madrid

Alba María Villar Gómez

Universidad Autónoma de Madrid

\section{Colaborador de edición / English editorial assistant}

\section{Kenneth Griffin}

Swansea University, Gales, Reino Unido

\section{Consejo de redacción}

Antonio Pérez Largacha

Universidad de Castilla - La Mancha

José Ramón Pérez-Accino Picatoste

Universidad Complutense de Madrid

Ma Covadonga Sevilla Cueva

Universidad Autónoma de Madrid

\section{Comité científico}

Josep Cervelló Autuori

Universitat Autònoma de Barcelona

María José López-Grande

Universidad Autónoma de Madrid

Josep Padró i Parcerisa

Universitat de Barcelona

M. ${ }^{a}$ Carmen Pérez Die

Museo Arqueológico Nacional, Madrid

Esther Pons Mellado

Museo Arqueológico Nacional, Madrid

José Miguel Serrano Delgado

Universidad de Sevilla 


\section{Trabajos de Egiptología}

Papers on Ancient Egypt

Número 7

2016 
Trabajos de Egiptología está producida por

Isfet. Egiptología e Historia

con la colaboración del Centro de Estudios Africanos

de la Universidad de La Laguna

$\mathrm{C} /$ Blanco 1, $2^{\circ}$

38400 Puerto de la Cruz

Tenerife-Islas Canarias

España

(C) De los textos: sus autores y Trabajos de Egiptología

Diseño de arte y maquetación

Marian Montesdeoca y Ulises Ramos

info@marianmontesdeoca.com

Imprime: Gráfica Los Majuelos

Depósito Legal: TF 935-2015

ISSN: 1695-4750 


\section{Contents}

$\begin{array}{lr}\text { Prefacio/Foreword } & 7\end{array}$

Chiefs, Kings, and Patrons. Leadership and Social Logics in the Beginnings of Ancient Egypt 9 Marcelo CAMPAGNO

The Development of Local Osirian Forms. An Explanatory Model

Lucía DÍAZ-IGLESIAS LLANOS

Shaushka, the Traveling Goddess

Graciela GESTOSO SINGER

What are we Talking about when we Talk about Memphis?

Maria Helena Trindade LOPES

Stone Vessels of Egyptian Appearance from Ibiza

María José LÓPEZ-GRANDE

The Argentine Archaeological Mission at Tell el-Ghaba. A Third Intermediate-Early Saite Period Site on the Ancient Egyptian Eastern Border. Remarks and Main Results Silvia LUPO

TT 209. Objectives of the proyecto dos cero nueve and the Name of the Tomb Owner Miguel Ángel MOLINERO POLO

The Herakleopolis Magna Project (Ehnasya el Medina). Summary and Results of Work 2000-2015

Tombs of the Roman Period in Sector 26 of the High Necropolis Archaeological Site of Oxyrhynchus, El-Bahnasa

Esther PONS MELLADO

The Decoration of the Pronaos of Petosiris' Tomb. Themes, Scenes, Styles and Techniques José das Candeias SALES

The Artist in his Context: New Tendencies on the Research of Ancient Egyptian Art 